\title{
The Impact of Operational Capabilities on Corporate Performance: Evidence from Listed Companies in the Agriculture, Forestry, Livestock Farming, Fishery Industry
}

\author{
Maoguo $\mathrm{Wu}^{1} \&$ Daimin $\mathrm{Lu}^{1}$ \\ ${ }^{1}$ SHU-UTS SILC Business School, Shanghai University, Shanghai, China \\ Correspondence: Maoguo Wu, SHU-UTS SILC Business School, Shanghai University, Shanghai, China. E-mail: \\ wumaoguo@shu.edu.cn
}

Received: February 16, 2019

Accepted: March 11, 2019

Online Published: March 12, 2019

doi:10.5430/afr.v8n2p56

URL: https://doi.org/10.5430/afr.v8n2p56

\begin{abstract}
In China, the agriculture, forestry, livestock farming, fishery (AFLF) industry is the basis of all industries. However, the overall development and performance level of listed companies in the AFLF industry is lower than the overall market level. According to previous literature, there is generally a positive impact of operational capabilities on the corporate performance of listed companies, but the impact on listed companies in the AFLF industry has not been investigated. This study attempts to fill in the gap by empirically analyzing the impact of operational capabilities on the corporate performance of listed companies in the AFLF industry in China. Based on a panel data set of 43 listed companies, this study performs regressions using a fixed effect model and a threshold panel model. The results show that there is a positive correlation between the operational capabilities and the corporate performance of listed companies in the AFLF industry, but different indicators that represent operational capabilities have different impacts on corporate performance. Based on the empirical results, this study puts forward corresponding suggestions for listed companies in the AFLF industry and policy makers.
\end{abstract}

Keywords: the agriculture, forestry, livestock farming, fishery industry, operational capabilities, corporate performance, threshold panel model

\section{Introduction}

Since ancient times, agriculture has been the basis for the subsistence of human society, the premise for the existence and development of other production sectors like the industrial sector, and the guarantee for the sustainable development of secondary and tertiary industries. In China with a population of nearly 1.4 billion, agriculture is closely related to people's livelihood, stability of the society, and economic development. In the agricultural industry chain, agriculture companies are an indispensable part of it, and they are also the representatives of advanced productive forces and abundant capital in the agricultural economy of the nation. However, by the end of 2017, there were only 43 listed companies in the agriculture, forestry, livestock farming, fishery (AFLF) industry in China A-shares, accounting for only 1.3\% of companies listed in Shanghai Stock Exchange and Shenzhen Stock Exchange. The overall income level of listed companies in the AFLF industry is lower than that of listed companies in other industries. Besides, their sustainable development ability is lower, their financial risk is higher, and some listed companies even have a negative impact on society. These problems are prevalent in listed companies in the AFLF industry in China. In addition, existing research on the impact of operational capabilities on corporate performance mainly focuses on the manufacturing industry. Research on the operational capabilities on the corporate performance of listed companies in the AFLF industry is scanty. Therefore, this study attempts to fill in the gap by investigating the impact of operational capabilities on the corporate performance of listed companies in the AFLF industry in China.

This study mainly contributes to three aspects. Firstly, for listed companies in the AFLF industry, empirical findings of this study can help them better evaluate their corporate performance, carry out active internal adjustment and reform, provide decision-making basis for them to get out of predicament, enhance their market competitiveness, and develop steadily in the long run. Secondly, empirical results provide the government with references, which may enable the government to carry out comprehensive and scientific macro-control and establish and improve the legal system related to agriculture, so listed companies can establish regulations and timely adjustments to the actual 
situation in order to promote the healthy development of agriculture. Thirdly, this study mainly investigates the impact of operational capabilities on the corporate performance of listed companies in the AFLF industry, an industry that previous research rarely explores. Empirical findings also provide reference for future research.

This study first reviews the theory of corporate performance evaluation of listed companies and the theory of the impact of operational capabilities on the corporate performance of listed companies. Based on previous literature, this study selects the explained variable, explanatory variables, and control variables. This study discusses the methods of corporate performance evaluation of listed companies in the AFLF industry and the impact of the explanatory variables, i.e., operational capabilities, on the corporate performance of listed companies in the AFLF industry. Then, based on the 10-year panel data set of 43 listed companies in the AFLF industry, this study establishes an econometric model including various variables and indicators suggested in previous literature. According to the regression results of the model, the impact of operational capabilities on the corporate performance of listed companies in the AFLF industry is analyzed. Policy suggestions are proposed accordingly.

\section{Related Literature}

A great deal of literature pertains to corporate performance evaluation. Since the 1950s, in order to strengthen corporate governance and mitigate agency problems which harm their own interests, investors have restrained the various behaviors of managers through corporate performance evaluation. Thereafter, with the development of production, Taylor (1912) put forward the scientific management theory. He believed that the production efficiency is the key to evaluate corporate performance, and in the process of production, attention should be paid to cost control. DuPont Corporation (1920) has designed many influential financial indicators. It has also pioneered the establishment of the first index of return on net assets and DuPont financial analysis system, which has promoted the formation of a comprehensive financial performance evaluation index system. Unlike the DuPont System Law, which focuses on financial performance evaluation, Wal (1928) innovatively proposed the Credit Capability Index and designed the Wal Scoring System accordingly. The system uses various financial indicators to evaluate the profitability and solvency of companies, and initiates the use of financial indicators to evaluate the comprehensive performance of companies. McKinsey (1932) added the macro-environmental factors into the corporate performance evaluation system. He believed that besides the internal factors, the overall macro-environment is also a factor influencing corporate performance. Simply aiming at the evaluation of the financial performance of a company, it is difficult to fully reflect the real operational capabilities of the company. Drucker (1995) regarded corporate social responsibility and long-term stability as two influencing factors of corporate performance evaluation. He held that companies should not take profit maximization as the sole goal, and that non-financial indicators should be combined with financial indicators to form a corporate performance evaluation system. With the deepening and development of economic globalization and economic integration, the traditional corporate performance evaluation methods, which mainly aim at saving production and operating costs and improving profits, have been unable to meet the needs of the new era. Stern Stewart Consulting Company (1991) established the Economic Value Added (EVA) index system which is still widely used today. The system can truly reflect the actual value created by a company, and correctly evaluate the business strategy of the company, which is conducive to better formulating the future development goals of the company.

$\mathrm{Xu}$ (2000) collected data from 812 listed companies and used factor analysis to study the corporate performance evaluation of listed companies. Pan et al. (2000) analyzed the financial data of 30 listed companies by principal component analysis, and found that the most important factor influencing the corporate performance of listed companies is the profitability of companies. Zhu (2004) established a corporate performance evaluation model of comprehensive factor analysis method and fuzzy method, combining the advantages of subjective and objective evaluation methods. Li (2004) measured and analyzed the corporate performance of more than 400 listed companies through principal component analysis and EVA analysis, and tested the correlation of corporate performance with main influencing factors. Li et al. (2005) established a comprehensive model for evaluating financial capability through analytic hierarchy process. Zhou et al. (2008) found that factor analysis, which reflects information of various financial indicators, is an objective performance evaluation method through comparative analysis. Han et al. (2007) used data envelopment analysis (DEA) to analyze the financial efficiency of 37 listed companies in the agriculture sector. Companies were divided into five categories: agriculture, forestry, livestock farming, fishery, and AFLF service. The financial data of these companies were grouped and analyzed, and the calculation of financial efficiency showed that the financial efficiency of the AFLF service segment was higher than that of livestock farming and fishery, and the reason for this phenomenon was mainly regarded to be related to the operational capabilities of companies. Xu (2008) also used factor analysis method to conduct empirical research on the data of listed companies in the AFLF industry. It was found that the corporate performance of listed companies in the AFLF 
industry exhibited an olive-shaped uneven distribution.

Despite the large amount of previous research on operational capabilities on corporate performance, previous research mainly focuses on the analysis of the relationship between operational capabilities and production efficiency, while research on the relationship between operational capabilities and corporate performance is scanty. Kritsonis (2004) proposed that the efficiency of corporate asset management can be effectively measured by the relevant ratio indicators of operational capabilities. If the relative ratio index is low, it indicates that the company's operational capabilities are low, and its assets cannot be effectively utilized, which may lead to additional interest charges on the company's funds, increase in the demand for funds, and decrease in the profit margin of capital. Ji et al. (2011) argued that operational capabilities are related to corporate performance. Through empirical analysis of the data of listed companies specialized in producing home appliances in China, they found that there is a high positive correlation between a company's operational capabilities and its corporate performance. Du et al. (2013) argued that if a company intends to improve its corporate performance, it should increase the turnover rate of its current assets to maintain a steady growth of its main business income, and at the same time, control the proportion of current assets at an appropriate level to improve the operational capabilities of the company's current assets.

Based on the above literature, this study finds that most of the existing research on the impact of operational capabilities on corporate performance focuses on the manufacturing industry, and very little on the AFLF industry, which is closely related to people's livelihood. Besides, most previous research does not consider operational capabilities or just uses operational capabilities as a supplementary factor in studying influencing factors of corporate performance. Moreover, factor analysis is used in most previous research, while other methods are seldom used. This study attempts to contribute to research on listed companies in the AFLF industry, and takes operational capabilities as the main factor that influences the corporate performance of listed companies in the AFLF industry. In terms of empirical methodology, this study uses the panel data regression model, rather than the commonly used factor analysis, because this method can make the impact of operational capabilities on corporate performance more scientifically and objectively reflected, which is convenient for interpretation and policy proposals.

\section{Institutional Background}

By the end of 2017, there were only 43 listed companies in the AFLF industry, among 3,513 A-share listed companies in Shanghai Stock Exchange and Shenzhen Stock Exchange, accounting for only $1.3 \%$ of the total number of listed companies. This reflects the small scale of the AFLF industry. At the same time, the overall assets of listed companies in the AFLF industry are also small. Taking the past five years as an example (from 2013 to 2017), the assets scale of listed companies in the AFLF industry is on the rise year by year, but there is still a big gap compared with listed companies in other industries. By the end of 2017, most of the total assets of listed companies in the AFLF industry in China were less than 5 billion yuan. In addition, the capital stock of listed companies in the AFLF industry in China is also smaller than that of other industries, which is not conducive to the formation of industrial economies of scale. By the end of 2017, the total equity of listed companies in the AFLF industry in China was basically less than 1 billion yuan, and only four listed companies had total equity of more than 2 billion yuan.

At present, industrial diversification is the development direction of most listed companies in the AFLF industry. Some companies gradually adopt management strategies to develop into other industries so as to improve economic efficiency. The consequence of such management strategies is less investment in the AFLF industry. Xia et al. (2011) found that the vast majority of listed companies in the AFLF industry invest in at least two industries, some even up to nine industries. At the same time, more and more listed companies in the AFLF industry are transforming from their original fields to other industries. For example, after the transformation from ocean fishery, they enter the computer application service industry, and some listed companies specialized in the development of grasslands is transformed into the development of coal mining and exploration. From the above two aspects, it can be seen that the current management situation of listed companies in the AFLF industry in China is developing in many ways across industries and gradually deviating from the direction of agriculture.

According to the 2017 annual report of listed companies in the AFLF industry, the overall benefits of listed companies in Shanghai Stock Exchange and Shenzhen Stock Exchange are difficult to reach the average market level, of which the average return on net assets is $-4.42 \%$, and the average inventory turnover and accounts receivable turnover are 3.03 and 29.06, respectively, which are less than $1 \%$ of the market average. In addition, the profitability of listed companies in the AFLF industry is also low. The average earnings per share is only 0.06 yuan, while the average of all listed companies is 0.45 yuan. From the above statistics, it can be clearly seen that the financial indicators of listed companies in the AFLF industry in China are far below the average level of the whole market. Therefore, it can be concluded that the overall efficiency of listed companies in the AFLF industry is low, the overall 
operating situation is very unstable, and the overall profitability and stable development ability of the industry need to be improved.

\section{Empirical Analysis}

Based on the previous literature discussed above, this study conducts an empirical analysis of the impact of operational capabilities on the corporate performance of listed companies in the AFLF industry. The data of 43 listed companies in the AFLF industry in recent ten years (2007-2016) are selected and analyzed. The main variables selected in this study are summarized in Table 1.

Table 1. Variable Description

\begin{tabular}{|c|c|c|c|}
\hline & \multicolumn{2}{|l|}{ Variable } & Variable Meaning \\
\hline $\begin{array}{l}\text { Explained } \\
\text { Variable }\end{array}$ & \multicolumn{2}{|l|}{ Return on Assets (ROA) } & $\begin{array}{l}\text { Ratio of pre-tax profit to average total } \\
\text { assets }\end{array}$ \\
\hline \multirow{6}{*}{$\begin{array}{l}\text { Explanatory } \\
\text { Variable }\end{array}$} & \multicolumn{2}{|l|}{ Operating Cycle (PERIOD) } & $\begin{array}{l}\text { Sum of inventory turnover days and } \\
\text { accounts receivable turnover days }\end{array}$ \\
\hline & $\begin{array}{ll}\text { Inventory } & \text { Turnover } \\
\text { (ITURNOVER) } & \end{array}$ & Ratio & $\begin{array}{l}\text { Ratio of operating cost to average } \\
\text { inventory }\end{array}$ \\
\hline & $\begin{array}{l}\text { Receivable } \\
\text { (RTURNOVER) }\end{array}$ & Rate & $\begin{array}{l}\text { Ratio of operating revenue to average } \\
\text { total accounts receivable }\end{array}$ \\
\hline & $\begin{array}{l}\text { Current Assets } \\
\text { (CATURNOVER) }\end{array}$ & Rate & $\begin{array}{l}\text { Ratio of operating revenue to average } \\
\text { total current assets }\end{array}$ \\
\hline & $\begin{array}{l}\text { Non-Current Assets } \\
\text { (NCATURNOVER) }\end{array}$ & Rate & $\begin{array}{l}\text { Ratio of operating revenue to average } \\
\text { total non-current assets }\end{array}$ \\
\hline & $\begin{array}{l}\text { Total Asset } \\
\text { (TATURNOVER) }\end{array}$ & & $\begin{array}{l}\text { Ratio of operating revenue to average } \\
\text { total assets }\end{array}$ \\
\hline & \multicolumn{2}{|l|}{ Quick Ratio (QR) } & $\begin{array}{l}\text { Ratio of quick assets to current } \\
\text { liabilities }\end{array}$ \\
\hline & \multicolumn{2}{|l|}{ Asset-Liability Ratio (DAR) } & $\begin{array}{l}\text { Ratio of total liabilities to total assets } \\
\text { at the end of the year }\end{array}$ \\
\hline Control Variable & \multicolumn{2}{|c|}{$\begin{array}{l}\text { Equity Attributable to Equity Holders of } \\
\text { the Company (EQUITY) }\end{array}$} & $\begin{array}{l}\text { The growth rate of shareholders' } \\
\text { equity relative to the beginning of the } \\
\text { year }\end{array}$ \\
\hline & \multicolumn{2}{|c|}{ Gross Operating Income (REVENUE) } & $\begin{array}{l}\text { Gross operating income growth rate in } \\
\text { the same period of the year }\end{array}$ \\
\hline & \multicolumn{2}{|l|}{ Total Assets (TASSET) } & $\begin{array}{l}\text { The growth rate of total assets in the } \\
\text { same period of the year }\end{array}$ \\
\hline
\end{tabular}

\subsection{Model Selection}

In order to avoid the influence of regression on the accuracy of the experiment, the unit root test on each variable is carried out first. It is found that all variables are stationary. Then, three basic models, OLS, random effect model, and fixed effect model, are compared to determine the most appropriate econometric model.

Firstly, the random effect model is compared with OLS. Breusch-Pagan Lagrangian Multiplier Test is used to compare the regression results of the random effect model with that of OLS. It is found that the random effect model is better than OLS. Then the F test finds that the fixed effect model is better than OLS. Finally, Hausman test finds that the fixed effect model outperforms the random effect model. Therefore, the fixed effect model is the most suitable econometric model for the data.

Because panel data are prone to endogeneity problems, this study conducts Davidson-McKinnon test to assess the endogeneity of the fixed effect model. Firstly, endogeneity tests on six core explanatory variables: operating cycle (PERIOD), inventory turnover (ITURNOVER), accounts receivable turnover (RTURNOVER), current asset turnover(CATURNOVER), non-current asset turnover (NCATURNOVER), and total asset turnover (TATURNOVER). Then, the first-order lag terms of these six variables are selected as the instrument variables one 
by one, and the test shows that there is no endogeneity problem for each variable.

Homoskedasticity is one of the basic assumptions of the fixed effect model. The random error term should satisfy the requirement of homoskedasticity, i.e., the variance of the random error $\mu$ is the same constant in different observation values. In order to ensure the reliability of the regression results, Wald heteroskedasticity test is used to test the heteroskedasticity of the observed values. It is found that the $\mathrm{P}$ value is less than 0.05 , i.e., the panel data set used in this study has very significant heteroskedasticity. Therefore, in order to make the regression results more reliable, this study utilizes the fixed effect model that controls heteroskedasticity.

\subsection{The Fixed Effect Model}

The econometric model, ideally, would be of the following form:

$$
\begin{gathered}
\text { ROA }=\alpha+\beta_{1} \text { PERIOD }+\beta_{2} \text { ITURNOVER }+\beta_{3} \text { RTURNOVER }+\beta_{4} \text { CATURNOVER } \\
+\beta_{5} \text { TATURNOVER }+\beta_{6} \text { NCATURNOVER }+\beta_{7} \mathrm{QR}+\beta_{8} \text { DAR }+\beta_{9} \text { EQUITY } \\
+\beta_{10} \text { REVENUE }+\beta_{11} \text { TASSET }+\mu,
\end{gathered}
$$

in which " $\alpha$ " is the intercept, and " $\beta_{i}$ " ( $\left.\mathrm{i}=1,2,3,4,5,6,7,8,9,10,11\right)$ is regression coefficient, and " $\mu$ " is random error term. Because the fixed effect model is the most appropriate econometric model and the panel data set has heteroskedasticity, this study conducts the following four regressions: Regression 1 is OLS that controls heteroskedasticity. Regression 2 is the fixed effect model that controls heteroskedasticity. Regression 3 is pooled OLS. Regression 4 is the asymptotic fixed effect model. Detailed regression results are shown in Table 2. Because of the presence of heteroskedasticity of panel data, the regression results of the fixed effect model that controls

\begin{tabular}{|c|c|c|c|c|}
\hline Variable & $\begin{array}{l}\text { Reg. } 1 \\
\text { Coef. } \\
\text { (t-value) }\end{array}$ & $\begin{array}{l}\text { Reg. } 2 \\
\text { Coef. } \\
\text { (t-value) }\end{array}$ & $\begin{array}{l}\text { Reg. } 3 \\
\text { Coef. } \\
\text { (t-value) }\end{array}$ & $\begin{array}{l}\text { Reg. } 4 \\
\text { Coef. } \\
\text { (t-value) }\end{array}$ \\
\hline PERIOD & $\begin{array}{l}-0.0193 \\
(-1.52)\end{array}$ & $\begin{array}{l}-0.0122 \\
(-0.78)\end{array}$ & $\begin{array}{l}-0.0193^{*} \\
(-2.18)\end{array}$ & $\begin{array}{l}-0.0122 \\
(-0.63)\end{array}$ \\
\hline ITURNOVER & $\begin{array}{l}-0.496 * * * \\
(-2.80)\end{array}$ & $\begin{array}{l}-0.178^{*} \\
(-1.89)\end{array}$ & $\begin{array}{l}-0.496^{* * *} \\
(-2.73)\end{array}$ & $\begin{array}{l}-0.178 \\
(-1.46)\end{array}$ \\
\hline RTURNOVER & $\begin{array}{l}0.00265^{* *} \\
(2.22)\end{array}$ & $\begin{array}{l}0.00125 \\
(1.53)\end{array}$ & $\begin{array}{l}0.00265^{* *} \\
(3.14)\end{array}$ & $\begin{array}{l}0.00125 \\
(1.66)\end{array}$ \\
\hline CATURNOVER & $\begin{array}{l}4.130 * * * \\
(4.20)\end{array}$ & $\begin{array}{l}5.084 * * * \\
(5.32)\end{array}$ & $\begin{array}{l}4.130 * * * \\
(4.87)\end{array}$ & $\begin{array}{l}5.084 * * * \\
(5.00)\end{array}$ \\
\hline NCATURNOVER & $\begin{array}{l}1.735 * * * \\
(2.64)\end{array}$ & $\begin{array}{l}2.186^{* * * *} \\
(3.22)\end{array}$ & $\begin{array}{l}1.735 * * * \\
(4.32)\end{array}$ & $\begin{array}{l}2.186^{* * * *} \\
(6.99)\end{array}$ \\
\hline TATURNOVER & $\begin{array}{l}-2.048 \\
(-0.58)\end{array}$ & $\begin{array}{l}1.210 \\
(0.30)\end{array}$ & $\begin{array}{l}-2.048 \\
(-1.41)\end{array}$ & $\begin{array}{l}1.210 \\
(0.68)\end{array}$ \\
\hline QR & $\begin{array}{l}-0.808 * * * \\
(-3.72)\end{array}$ & $\begin{array}{l}-0.476^{* *} \\
(-2.56)\end{array}$ & $\begin{array}{l}-0.808 * * * \\
(-4.95)\end{array}$ & $\begin{array}{l}-0.476^{* *} \\
(-2.39)\end{array}$ \\
\hline DAR & $\begin{array}{l}-0.0915 * * * \\
(-3.12)\end{array}$ & $\begin{array}{l}-0.139 * * \\
(-2.35)\end{array}$ & $\begin{array}{l}-0.0915 * * * \\
(-3.98)\end{array}$ & $\begin{array}{l}-0.139 * * \\
(-2.63)\end{array}$ \\
\hline EQUITY & $\begin{array}{l}0.0167 * * * \\
(2.86)\end{array}$ & $\begin{array}{l}0.0130^{* *} \\
(2.47)\end{array}$ & $\begin{array}{l}0.0167 * * \\
(2.73)\end{array}$ & $\begin{array}{l}0.0130 * \\
(2.18)\end{array}$ \\
\hline REVENUE & $\begin{array}{l}-0.0000813 * \\
(-1.82)\end{array}$ & $\begin{array}{l}-0.0000236 \\
(-0.61)\end{array}$ & $\begin{array}{l}-0.0000813 \\
(-1.72)\end{array}$ & $\begin{array}{l}-0.0000236 \\
(-0.41)\end{array}$ \\
\hline TASSET & $\begin{array}{l}0.0419^{* *} \\
(2.43)\end{array}$ & $\begin{array}{l}0.0261^{*} \\
(1.71)\end{array}$ & $\begin{array}{l}0.0419^{*} \\
(2.21)\end{array}$ & $\begin{array}{l}0.0261 \\
(1.42)\end{array}$ \\
\hline CONSTANT & $\begin{array}{l}3.998 * * \\
(2.55)\end{array}$ & $\begin{array}{l}0.778 \\
(0.32)\end{array}$ & $\begin{array}{l}3.998 * * \\
(2.41)\end{array}$ & $\begin{array}{l}0.778 \\
(0.36)\end{array}$ \\
\hline $\mathrm{N}$ & 353 & 353 & 353 & 353 \\
\hline
\end{tabular}
heteroskedasticity are interpreted.

Table 2. Regression Results and Robustness Check

Note: $* * *, * *, *$ denotes significant at the $1 \%, 5 \%$, and $10 \%$ significance level, respectively. 
Table 2 shows that there is no significant correlation between operating cycle and ROA among explanatory variables. Inventory turnover is negatively correlated with ROA, and is significant at the $10 \%$ significance level. It shows that for listed companies in the AFLF industry in China, the particularity of agricultural products leads to higher inventory turnover but lower corporate performance. There is a positive correlation between the turnover rate of accounts receivable and ROA, but it is not significant. This shows that measures that only improve the turnover rate of accounts receivable and reduce bad debts have no obvious effect on the improvement in corporate performance. The turnover rate of current assets is positively correlated with ROA, and is significant at the $1 \%$ significance level. This result shows that if listed companies in the AFLF industry can pay attention to the management of the current assets and increase their efficiency, they can significantly improve the corporate performance and promote long-term development. Non-current assets turnover rate is positively correlated with ROA and is significant at the 1\% significance level, which indicates that the turnover of non-current assets, which accounts for the majority of assets of listed companies in the AFLF industry, can greatly affect the operating efficiency of companies, thus affecting the overall performance level. Total asset turnover is not very significant in the regression, but it still has a positive correlation with ROA, because total assets are composed of current assets and non-current assets, and both of them are positively related to ROA.

Regarding the impact of control variables, QR is negatively correlated with ROA and is significant at the 5\% significance level. This implies that most of the listed companies in the AFLF industry possess a large proportion of accounts receivable, which increases the possibility of bad debts and reduces the quick ratio of listed companies. Besides, it is not conducive to long-term development of listed companies. DAR is also negatively correlated with ROA and is significant at the 5\% significance level. This is consistent with most previous research results. The higher the DAR of a listed company, the higher the proportion of the listed company is financed by borrowing, which increases the operational risk of the listed company. EQUITY is positively correlated with ROA and is significant at the 5\% significance level. This shows that the growth of shareholders' equity represents the growth of corporate profits, and thus the total asset remuneration also increases. There is no significant correlation between REVENUE and ROA. TASSET is positively correlated with ROA and is significant at the $10 \%$ significance level. The increase in total assets enhances the rate of return on total assets and improves the overall performance.

\subsection{The Threshold Panel Model}

Besides utilizing the fixed effect model that controls heteroskedasticity for the empirical tests, this study also utilizes the threshold panel model, and takes earnings per share (EPS), the ratio of after-tax profit to total equity, as an explanatory variable, to explore how the level of per share income influence the corporate performance of listed companies in the AFLF industry.

The premise of the threshold panel model is that the threshold variables are stationary, so the unit root test of the additional variable, EPS, is conducted. At the same time, in order to ensure that the threshold variable is exogenous, Davidson-McKinnon test is performed. The test results show that the variable EPS is both stationary and exogenous.

In addition, before establishing the threshold panel model, it is necessary to determine whether there is a threshold effect of earnings per share, and to determine whether there are several thresholds in the model and to find out the threshold values. In this study, the threshold value is tested by Bootstrap method. The number of sampling is 300 , and the significance level is $1 \%, 5 \%$, and $10 \%$, respectively. The test results are shown in Table 3 .

Table 3. Threshold Effect Bootstrap Test

\begin{tabular}{lllllll}
\hline \multirow{2}{*}{ Model } & \multirow{2}{*}{ F-Value } & \multirow{2}{*}{ P-Value } & \multirow{2}{*}{ Number of BS } & \multicolumn{2}{l}{ Critical Value } & \\
& & & & $1 \%$ & $5 \%$ & $10 \%$ \\
\hline Single Threshold & $62.952^{* * *}$ & 0 & 300 & 29.845 & 20.904 & 14.465 \\
Double Threshold & $16.445^{* *}$ & 0.040 & 300 & 26.393 & 14.363 & 10.410 \\
Triple Threshold & 0 & 0.080 & 300 & 0 & 0 & 0 \\
\hline
\end{tabular}

Note: $* * * * *$, and $*$ denotes significant at the $1 \%, 5 \%$, and $10 \%$ significance level, respectively.

From Table 3, it can be seen that the p-value of bootstrap test of the single threshold model and the double threshold model is less than 0.05 , while the p-value of the triple threshold model is greater than 0.05 , which shows that there are only two thresholds in the sample selected for this study.

After confirming the threshold effect of earnings per share, this study estimates and tests these two thresholds. When the significance level is $5 \%$, the critical value of Likelihood Ratio (LR) statistics is 7.40 . Based on this, the trend 
chart of LR value changing with threshold parameters is drawn (Figure 1, Figure 2, and Figure 3). The estimation of the threshold value and confidence interval can be more intuitively understood by the trend diagram. When LR is 0 , the value of $\gamma$ is the estimation of the threshold parameter. The dashed line in each graph represents the critical value of LR, and the interval of the value of $\gamma$ corresponding to the LR value below the dashed line is the confidence interval of the two threshold variables at the $95 \%$ confidence level.

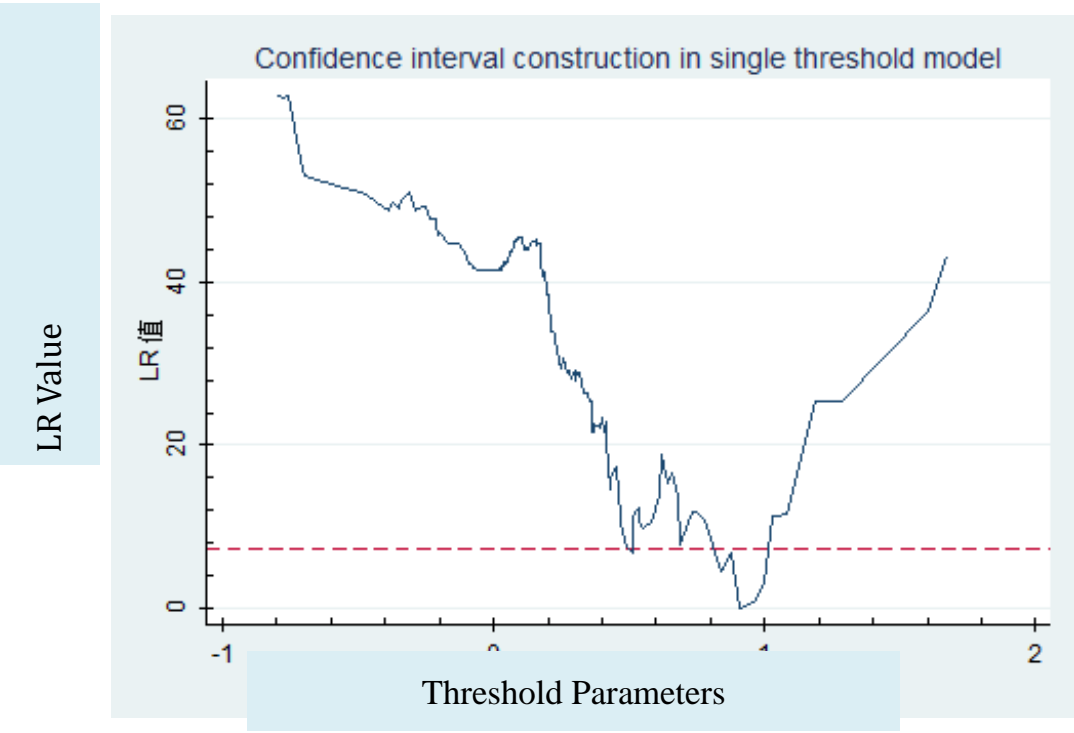

Figure 1. The Single Threshold Model

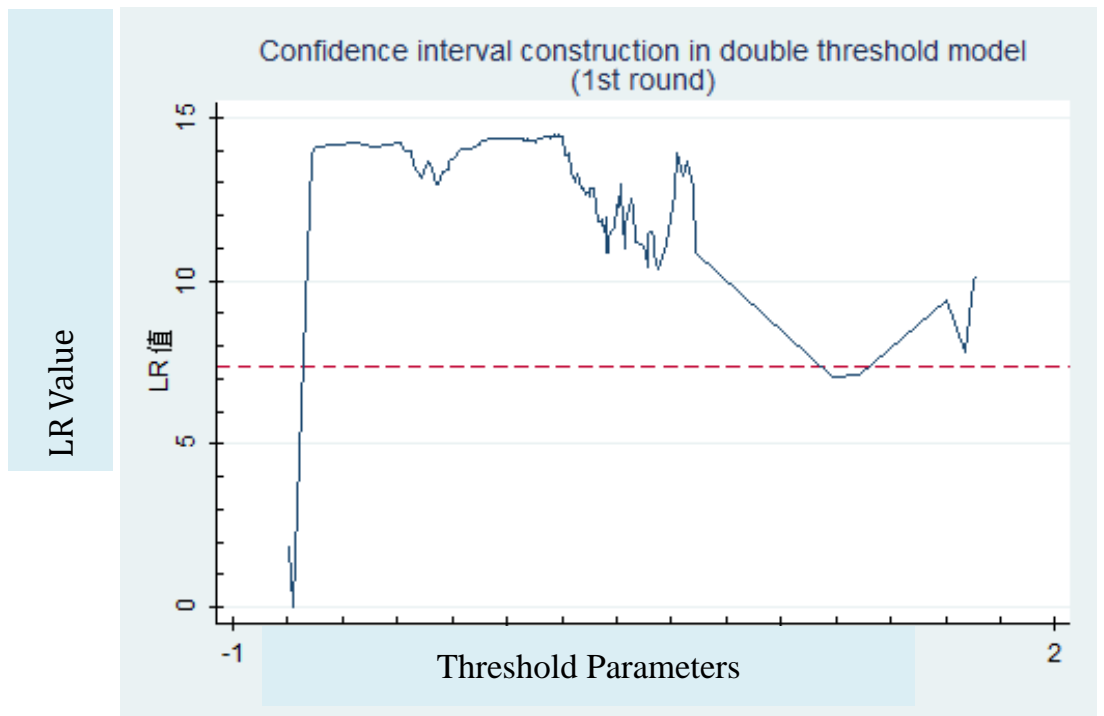

Figure 2. The Double Threshold Model (The First Threshold) 


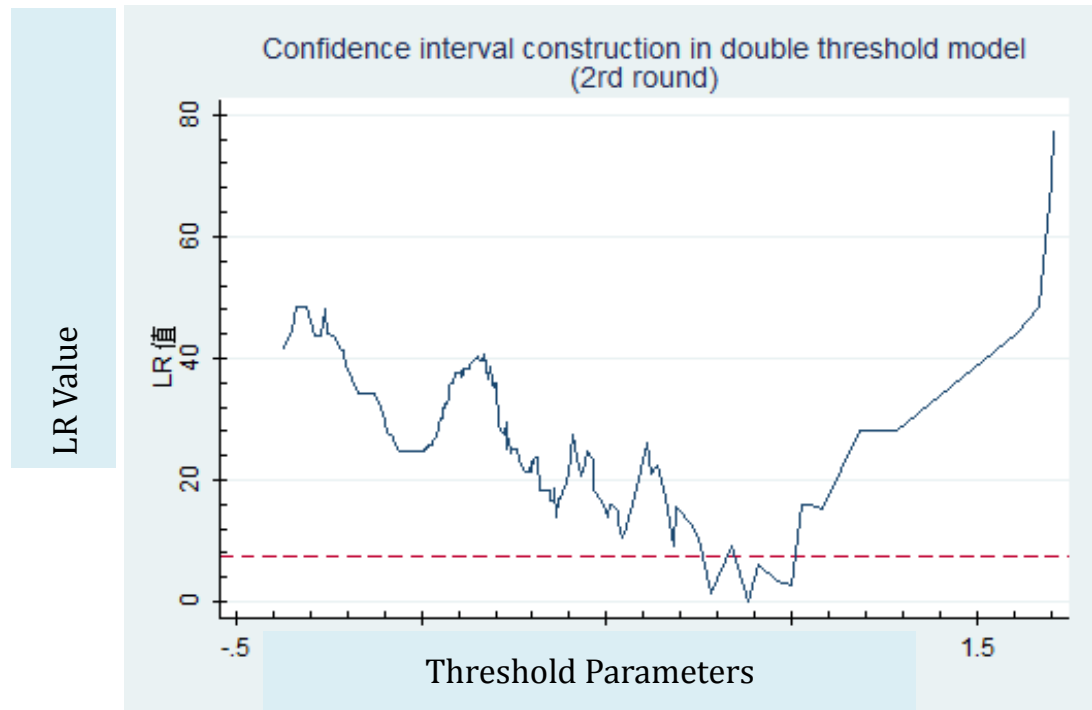

Figure 3. The Double Threshold Model (The Second Threshold)

This study calculates that the threshold value of the single threshold model is $0.910 \%$, and its $95 \%$ confidence interval is $[0.502,1.000]$. The first threshold value of the double threshold model is $-0.780 \%$, and its $95 \%$ confidence interval is $[-0.795,1.285]$. The second threshold value is $0.880 \%$, and its $95 \%$ confidence interval is $[0.780,1.000]$. Then, a regression model for ROA is established.

$$
\begin{gathered}
\text { ROA }=\alpha+\beta_{1} *{ }^{*} \text { EPS }\left(E P S \leq \gamma_{1}\right)+\beta_{2} *{ }^{*} \text { EPS }\left(\gamma_{1} \leq \text { EPS } \leq \gamma_{2}\right)+\beta_{3} * I * E P S\left(E P S \geq \gamma_{2}\right) \\
+\beta_{4} \text { PERIOD }+\beta_{5} \text { ITURNOVER }+\beta_{6} \text { RTURNOVER }+\beta_{7} \text { CATURNOVER } \\
+\beta_{8} \text { TATURNOVER }+\beta_{9} \text { NCATURNOVER }+\beta_{10} Q R+\beta_{11} \text { DAR } \\
+\beta_{12} \text { EQUITY }+\beta_{13} \text { REVENUE }+\beta_{14} \text { TASSET }+\mu
\end{gathered}
$$

in which " $\alpha$ " is the intercept, and " $\beta_{i}$ " ( $\left.\mathrm{i}=1,2,3,4,5,6,7,8,9,10,11,12,13,14\right)$ is the coefficient, $\mu$ is the random error term, and $\gamma_{i}(\mathrm{i}=1,2)$ is the threshold value with $\mathrm{i}$ being the indicator. When the condition is established, it is 1 or 0 .

The regression results are shown in Table 4. Regression 1 is the panel threshold model. Regression 2 is the fixed effect model that controls heteroskedasticity and includes the level of earnings per share as an additional explanatory variable. Regression 3 is the fixed effect model that controls heteroskedasticity and includes squared earnings per share (EPSSQR) to capture the nonlinear relationship between the two variables. The results of the panel threshold model are shown in Table 4. 
Table 4. Regression Results and Robustness Check

\begin{tabular}{|c|c|c|c|}
\hline Variable & $\begin{array}{l}\text { Reg. } 1 \\
\text { Coef. } \\
\text { (t-value) }\end{array}$ & $\begin{array}{l}\text { Reg. } 2 \\
\text { Coef. } \\
\text { (t-value) }\end{array}$ & $\begin{array}{l}\text { Reg. } 3 \\
\text { Coef. } \\
\text { (t-value) }\end{array}$ \\
\hline EPS & & $\begin{array}{l}15.25^{* * * *} \\
(11.61)\end{array}$ & \\
\hline EPSSQR & & & $\begin{array}{l}-0.848 \\
(-0.57)\end{array}$ \\
\hline EPS $<-0.780$ & $\begin{array}{l}15.210^{* * * *} \\
(16.36)\end{array}$ & & \\
\hline$-0.780<=$ EPS $<0.880$ & $\begin{array}{l}20.01 * * * \\
(22.44)\end{array}$ & & \\
\hline $\mathrm{EPS}>0.880$ & $\begin{array}{l}11.72 * * * \\
(16.83)\end{array}$ & & \\
\hline PERIOD & $\begin{array}{l}-0.00637 \\
(-0.97)\end{array}$ & $\begin{array}{l}-0.0100 \\
(-1.11)\end{array}$ & $\begin{array}{l}-0.0132 \\
(-0.89)\end{array}$ \\
\hline ITURNOVER & $\begin{array}{l}0.0315 \\
(0.45)\end{array}$ & $\begin{array}{l}0.0520 \\
(0.81)\end{array}$ & $\begin{array}{l}-0.172^{*} \\
(-1.75)\end{array}$ \\
\hline RTURNOVER & $\begin{array}{l}-0.000258 \\
(-0.28)\end{array}$ & $\begin{array}{l}-0.000239 \\
(-0.48)\end{array}$ & $\begin{array}{l}0.00102 \\
(1.41)\end{array}$ \\
\hline CATURNOVER & $\begin{array}{l}2.592 * * * \\
(3.91)\end{array}$ & $\begin{array}{l}1.830 * * * \\
(2.99)\end{array}$ & $\begin{array}{l}5.272 * * * \\
(5.02)\end{array}$ \\
\hline TATURNOVER & $\begin{array}{l}-3.661^{*} \\
(-1.70)\end{array}$ & $\begin{array}{l}0.777 \\
(0.34)\end{array}$ & $\begin{array}{l}0.869 \\
(0.19)\end{array}$ \\
\hline NCATURNOVER & $\begin{array}{l}0.849^{* *} \\
(2.50)\end{array}$ & $\begin{array}{l}0.765^{* *} \\
(2.15)\end{array}$ & $\begin{array}{l}2.136 * * * \\
(3.04)\end{array}$ \\
\hline QR & $\begin{array}{l}0.0174 \\
(0.15)\end{array}$ & $\begin{array}{l}0.0845 \\
(0.73)\end{array}$ & $\begin{array}{l}-0.443 * * \\
(-2.47)\end{array}$ \\
\hline DAR & $\begin{array}{l}0.0596^{* * * *} \\
(3.55)\end{array}$ & $\begin{array}{l}0.0840 * * * \\
(3.07)\end{array}$ & $\begin{array}{l}-0.135^{* *} \\
(-2.24)\end{array}$ \\
\hline EQUITY & $\begin{array}{l}0.00729 * * \\
(2.22)\end{array}$ & $\begin{array}{l}0.0122 * * * \\
(2.81)\end{array}$ & $\begin{array}{l}0.0129 * * \\
(2.51)\end{array}$ \\
\hline REVENUE & $\begin{array}{l}0.0000985 * * * \\
(3.11)\end{array}$ & $\begin{array}{l}0.0000993 * * * \\
(4.21)\end{array}$ & $\begin{array}{l}-0.0000180 \\
(-0.47)\end{array}$ \\
\hline TASSET & $\begin{array}{l}-0.0157^{*} \\
(-1.88)\end{array}$ & $\begin{array}{l}-0.0211^{* *} \\
(-2.19)\end{array}$ & $\begin{array}{l}0.0241 \\
(1.61)\end{array}$ \\
\hline CONSTANT & $\begin{array}{l}-2.966^{* * *} \\
(-3.19)\end{array}$ & $\begin{array}{l}-5.154 * * * \\
(-3.54)\end{array}$ & $\begin{array}{l}0.993 \\
(0.38)\end{array}$ \\
\hline $\mathrm{R}^{2}$ & 0.924 & 0.911 & 0.918 \\
\hline
\end{tabular}

Note: $* * *, * *$, and * denotes significant at the $1 \%, 5 \%$, and $10 \%$ significance level, respectively.

From Table 4, it can be seen that the goodness of fit of the double threshold panel model for the above variables is 0.924 , slightly higher than the multiple linear model and the quadratic function model, and the regression results of each stock return are also better. Therefore, the relationship between earnings per share and return on net assets cannot be simply explained by multiple linear model or quadratic function model. Instead, it is more similar to a piecewise linear function relationship. The two thresholds of earnings per share divide the relationship between earnings per share and return on net assets into three intervals. The trend of the relationship between earnings per 
share and return on net assets at different stages can be roughly depicted by Figure 4.

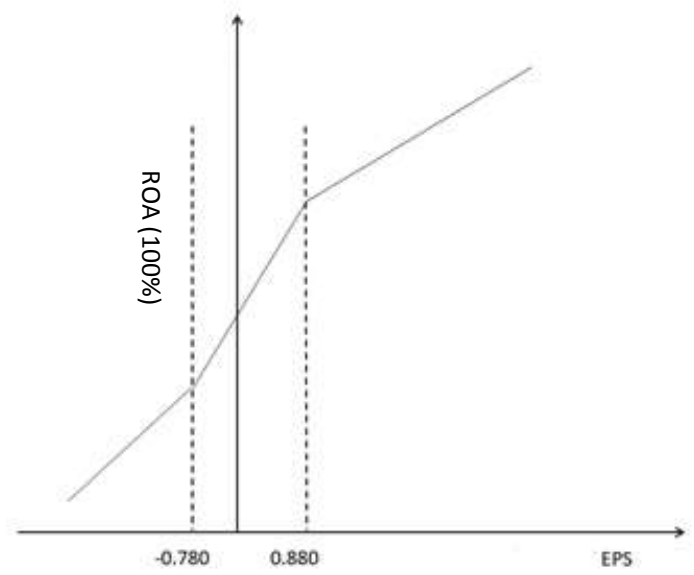

Figure 4. The Impact of Earnings Per Share on ROA

When the earnings per share of listed companies in the AFLF industry are below -0.780 yuan, the variable earnings per share is positively correlated with corporate performance with a coefficient of 15.210 , which means that when the company sets the earnings per share at a low level, every increase in earnings per share of 1 yuan will increase the company's ROA by $15.210 \%$. When the earnings per share are between -0.780 yuan and 0.880 yuan, the earnings per share show a more significant positive correlation with a coefficient of 20.010. This shows that earnings per share in this range can significantly improve the overall performance of the company. When earnings per share are higher than 0.880 yuan, the positive correlation between earnings per share and corporate performance begins to weaken, and the coefficient drops to 11.72. This shows that when earnings per share are at a high level, other risks begin to increase, and the effect of earnings per share on improving the overall performance of the company is weakened, so other factors need to be considered.

\section{Conclusion}

This study investigates a panel data set of listed companies in the AFLF industry in China from 2007 to 2016. Through the fixed effect model that controls heteroskedasticity, the operating cycle, inventory turnover, ratio of accounts receivable, turnover of current assets, turnover of non-current assets, and turnover of total assets are analyzed with the control variables of quick ratio, asset-liability ratio, equity attributable to equity holders of the company, total operating income, and total assets. The relationship between the six explanatory variables of operational capabilities and the corporate performance of listed companies in the AFLF industry in China is studied. From the regression results, this study draws the following conclusions: there is a positive correlation between the operational capabilities and the corporate performance of listed companies in the AFLF industry. To be specific, for listed companies in the AFLF industry, the stronger the operational capabilities of a company, the better the corporate performance of the company. This is consistent with previous literature that there is a positive correlation between operational capabilities and corporate performance in other industries, but the relationship between financial indicators representing operational capabilities and corporate performance is quite different. There is a significant positive correlation between current assets turnover rate and non-current assets turnover rate and the corporate performance of listed companies in the AFLF industry, but the correlation between operating cycle, accounts receivable turnover rate, and total assets turnover rate and corporate performance is not very significant.

Therefore, based on the empirical results, this study puts forward the following suggestions for listed companies in the AFLF industry. Firstly, listed companies should continuously improve their operational capabilities, rationally allocate resources and improve the efficiency of asset use. Secondly, listed companies should enhance the solvency, adjust the debt structure, and make rational use of financial leverage. Thirdly, listed companies should expand profitability, strengthen technological innovation, and adjust business models. Fourthly, listed companies should promote the optimization and restructure of themselves, develop strategic alliances among companies, and form economies of scale.

In addition, from the government level, government is encouraged to create a good external environment for listed 
companies in the AFLF industry, and promote the sound development of listed companies. For example, at the institutional level, it provides good conditions for listed companies in the AFLF industry. Besides, government is encouraged to further establish and improve the price system of AFLF products, and gradually establish a price mechanism of AFLF products with Chinese characteristics, which combines market regulation with state guidance. At the same time, the government should continue to support listed companies in the AFLF industry, but it should adopt more effective and flexible ways rather than simple and crude direct subsidies, such as subsidies for the introduction of relevant talents and scientific research and innovation of listed companies in the AFLF industry. The government is suggested enhancing listed companies' soft power to enhance their core competitiveness, so as to improve the overall profitability and promote the long-term development of listed companies.

Regarding limitation, this study only chooses a partial selection of representative indicators of operational capabilities as explanatory variables, not all the financial indicators representing operational capabilities. The selection may to some extent affect the regression results. In order to obtain a balanced data set for the threshold panel data model, this study removes some listed companies, which did not fully disclose their financial information. The remaining data may suffer from survival bias. Despite all operating in the same industry, the main business of each listed company in the AFLF industry differs significantly, and the operational capabilities, profitabilities, and liabilities of each listed company also vary, future studies will add in individual-fixed effects to control for heterogeneity.

\section{References}

Drucker, P. Corporate Performance Evaluation. Beijing: Chinese People's Humanities Publishing House.

Du, J., Liu, J. \& Zeng, S. (2013). Empirical Study on the Operational Capabilities and Profitability of Liquidated Assets of Listed Companies: Illustrated by the Example of the Liquor Industry (in Chinese). Financial Communication, (02).

Han, S., Wang, B. \& Hou, J. (2007). Financial Performance Analysis of Listed Companies in the Agricultural Industry (in Chinese). Anhui Agricultural Science, 18(03), 38-42

Ji, J. \& Li, H. (2011). The Correlation between Operational Capabilities and Corporate Performance (in Chinese). New Accounting, (04), 11-13

Kritsonis, A. (2004). Assessing A Firm's Future Financial Health. International Journal of Scholarly Academic Intellectual Diversity, (09).

Li, N. \& Li, X. (2005). Evaluation Model and Application of Corporate Financial Ability [J] (in Chinese). Financial Communication, (07), 70-71.

Li, X. (2008). Analysis System of Corporate Operational Capabilities (in Chinese). Modern Economic Information, (07), 98-101.

Pan, Y. \& Cheng, X. (2000). Principal Component Evaluation Method for the Corporate Performance of Listed Companies (in Chinese). Accounting Research, (01), 31-35.

Taylor, F. Principles of Scientific Management. Beijing: Mechanical Industry Press.

Xia, X., Zhang, X. \& Ren, J. (2011). The Impact of Diversification on the Corporate Performance of Listed Companies in the Agricultural Industry (in Chinese). Monthly Journal of Finance and Accounting, (7), 28-30.

Xu, G. (2000). Comprehensive Evaluation and Empirical Study on the Corporate Performance of Listed Companies (in Chinese). Statistical Research, (09).

Xu, X. \& Ma, J. (2008). The Performance Evaluation of Listed Companies in the Agricultural Industry (in Chinese). Guizhou Social Science, 16(08), 66-72.

Zhou, H. \& Wang, H. (2008). Performance Forms of Relative Performance Evaluation [J] (in Chinese). Accounting Research, (06), 72-96.

Zhu, Z. (2004). Comprehensive Evaluation of the Corporate Performance of Listed Companies in the Home Appliances Industry (in Chinese). Management Review, (01). 